5.

旨

手近な材料約 10 種を混合材とせる混合セメントを試製し，その 規格抗張力，軟練モルタルの 1 26 週及び聯結强度，硫酸液浸漬及 び加熱後の强度等を測定し，これを別府白土の試製セメントと比較 して見た。
（1）靑森ベントナイト 2 種は別府白土と同等の成績を示した。

(2) 粕塚山陚石, 不英粗面岩, 花崗岩分解物等七更に 呼究の價值 がある。

終りに本實驗は山本獎學資金の補助を受けた。爱に謝意を表する 次第である。(東京工業大學筧業學科工場)

\title{
Abstract
}

\section{A STUDY OF MIXED PORTLAND CEMENT}

By Seiji Kondo \& Aitaro Miyagawa

8 mixed portland cements were prepared of $70 \%$ of a portland cement clinker, and $30 \%$ of a high grade kaolin, a quartz s and, apyrophyllite, a potter's rock, "Hakudo " (white earth) of Beppu, 2 bentonites of Aomori, a liparite, and a decomposed granite for the purpose of comparing these mixing materials to the white earth which is used in the commercial production of the mixed cement. The mixing materials had been ignited at temperatures varying from $750^{\circ}$ to $900^{\circ} \mathrm{C}$. Then the cements have been examined for $\mathrm{sp}$. $\mathrm{gr}$., setting time, soundness, tensile strength of the Japanese Cement Specifications, and also for modulus of rupture and compressive strength of wet mortars at the ages of 1, 4, and 26 weeks. The wet mortars were prepared of 1 pt. of cement, 1 pt. of fine kumiho sand, and 2 pt. of Standard Sand, and such amounts of water as required for a definite flow. The wet mortars have also been examined for the modulus and strength on combined hardening, those on immersion in 1\% sulphuric acid for 27 days, and for those on heating 4 week specimens at $500^{\circ} \mathrm{C}$.

(1) Both bentonites seem to be as good as the white earth.

(2) 'The potters' rock, liparite, and decomposed granite are promising and have to be investigated furthere.

(Dept. of Ceramic Engineering, Tokio University of Engineering)

\section{收塵或は選粒選粒に就て(第 2 報)}

\section{磯部純 一}

\section{緒謇}

著者は第 I 報（本誌，昭 14，47，[553]19）に於て收麈裝置と して普通に用ひられてるる粒歴の自然沈下゙を利用する收塵裝置の收 塵機構を研討するに便利でもる樣に平面に並行な定常流の中に流動 する粒子の運動式として

$$
\left.\begin{array}{l}
y=\frac{(4 \rho+\sigma)(\rho-\sigma)}{81 \eta^{2}} g r^{4}\left(e^{\frac{-9 \eta x}{(2 \rho+\sigma) r^{2} U}}-1\right)+\frac{2 \rho-\sigma) r^{2} g}{9 \eta U} x \\
z=B
\end{array}\right\} \cdots(16)
$$

を與へた。本報告に於てはこの（16）式の表す粒子の運動軌跡を 圖解し，斯如き運動を利用して收塵或は選粉選粒を行ふ場合の主要 條件を摘記しこの種裝置として備ふべき要件を述べ，更にこの要件 が正しいかどうかを調べた實驗の詳細に就て記述しようと思ふ。

\section{v. 粒子の運勤橿䟽}

流體の種類，流體の條件及粒子の密度等が與へられれば流體中の 或一點より運動を初める粒子の運動軌跡は計算される筈である。今 水平面に並行に一定速度を以て定常狀態で流れてるる流䣓中の粒子 の理論上の運動軌跡を求めようとすれば (16) 式を計算することによ り簡單に求めることが出來る。この具體例を示すのに流體が氯體で ある場合を考へるに氣體の密度は固體に比して甚げかさく学力及び
加速度運動に對与る補整等はこれを無視して差支へない。依而 (61) 式は

$$
\begin{aligned}
& y=\frac{4^{\rho 2} g r^{4}}{81 \eta^{2}}\left(e^{\frac{-9 \eta x}{2 \rho \eta^{2} U}}-1\right)+\frac{2 \rho r^{2} g}{9 \eta U} x \cdots \cdots \cdots \cdots \cdots \cdots(17)
\end{aligned}
$$

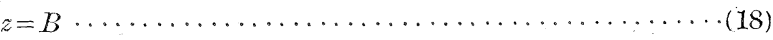

となり各係數常數が與へられれば $r, x, y, z$ の關係が知られる。 今流體の密度を 0.001 瓦/立方糎, 粘性係數を 0.00023 瓦粝, 秒, 流 速を 100 粝/秒とし粉塵の密度を 2.5 瓦/立方糎としてこれ等の關係 を求めて見る。(18) 式より $B$ は任意の常數であるが故に $Z$ 軸上の 或一點で成立する $x, y, r$ の關係は $Z$ 軸上のすべての點で成立する 鹪特に $Z$ を考虑に大れる必要がない。故に運動軌跡は(17) 式だけ を計算すれればよいこになる。今 (17) 式に於て $r=100 \mu$ (ミクロ ン), $50 \mu, 20 \mu, 10 \mu, 5 \mu$ の場合の $x, y$ の關係を求むれば第 1 圖の 樣になり粒子中征の大なるものは非常に早く沈下し徑が小さくなる 程沈下が困難となり流される距離が大となる。この概念は特に新ら しいことではなく圖示を待たなくとも常識的に至極容易に考へられ る事柄である。この式及軌跡圖の有する意味はこの種連動を利用し て行ふ收歴或は選粉選粒に於てその限度と條件とを明示することで 勿論實際の收塵室或は選粉選粒室に於ては內部の流體の流れが各種 


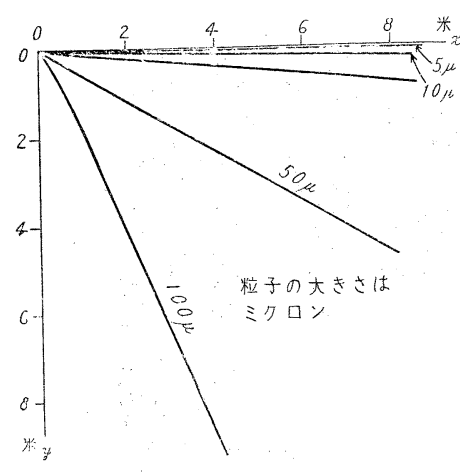

䈍 1 圖流體中の粒子の運動軌跡 流體 密度 0.001 粗性係數 0.00023 流速 100

粒子 密度 2.5 單位糎, 瓦, 秒
の原因により動摇する篇 (17) 式より直に明確な限度 と條件とを決定することは 山來ないが概略的な限界は 制斷出來ると思はれる。依 而第 1 圖より充分よく知ら れることではあるが更に (17) 式の示す主要條件を明 瞭にする䉆粉塵の沈下すべ き距離 $y$ が與へられた時の $r$ と $x$ との關係を求めて見 る。(17)式に於て $y$ を1米 2 米, 4 米等にとれば各場合 に於ける $\dot{r}$ と $x$ との關係 は第2圖となる。圖より明 かに高さ 4 米の收塵室を用ひて半徑 $30 \mu$ 以上の粒子を完全に沈下さ せるには收塵室の實效長を16.7 米としなければならないが高さ2米

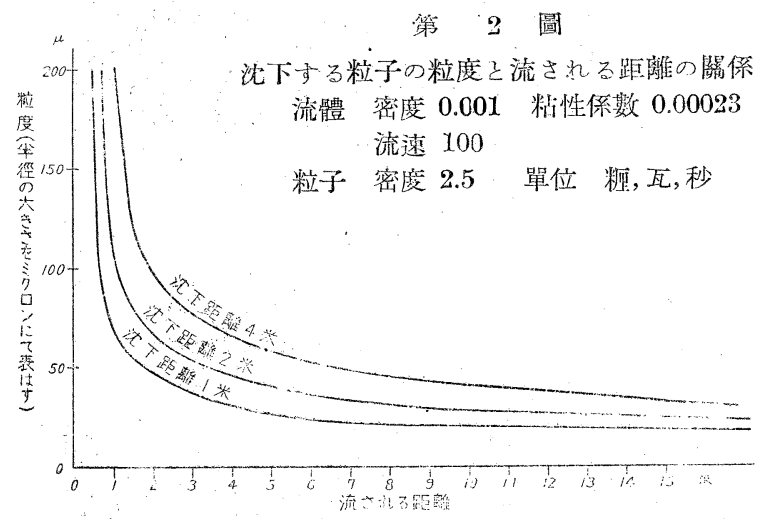

の收塵室を用ひれば收蝔室長は 8.37 米でよく更に高さ1米の收塵室 を用ひればその室長は 4.2 米でよいことが解る。以上は流體として 氣體を選んだ結果であるが流體を液體としても同樣である。郎ち流 水中の砂泥の沈下を例示すれば水溫 $15^{\circ} \mathrm{C}$ 流速 1 米の水中に流動す る砂泥の密度を 2.5 瓦/立方糎すとれば水の密度は 0.999 瓦/立方糎, 粘性係數は 0.0114 瓦糎秒である故これ等の值を(16)式に代大すれ ば $r, x, y$ の關係が得られる。これを第 2 圖を求めたと同樣にして 沈砂值の深さ $y$ を與へて $r, x$ の關係を求めるに, $y=100$ 糎, 200 粧，400 糎とすれば各場合に於ける $r$ と $x$ との關係は第 3 圖に示

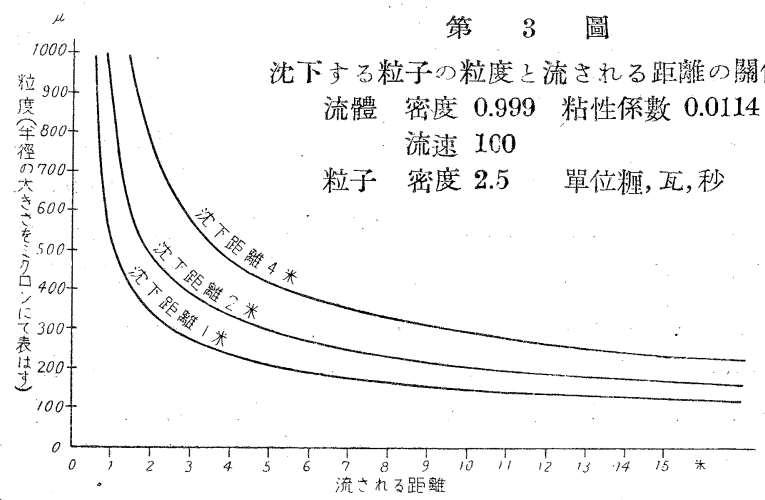

す樣になる。郎ち深さ 4 米の沈砂池に依つて $200 \mu$ 以上の砂泥を完 全に除去する篇には沈砂池實效長は 21.8 米なければならないが深さ 2 米の沈砂池を用ひれば池の長さは 10.9 米で充分であり更に深さ 1 米の沈砂池を用ひる時は池の長さは 5,48 米でよいことがわかる。
選粉, 選粒に關しては既に述べたことより容易に察知出來る樣に 室高を高くすれば粒子の大きさにより粒子の落達距離が著しく違つ て來る故目的に應じて適當にその室高を高く選び所要の大きさの粒 子の落澾位置に於てその長さを短かく選ぶべきである。 佾式より明 かである樣に流速が室高, 室長と同樣, 收塵, 選粉選粒に重大な影響 を及ぼすこと勿論である。

以上の結果より收塵室或は選粉選粒窒としての必要條件を摘出す れば收魔室としては

1. 室高は出來る限り低く選が。

2. 室長は出來る限り長く選ぶ。

3. 室內の流速は出來る限り低速とする。

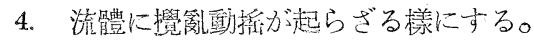
の項目が舉げられ選粉, 選粒室としては

1. 室高は高く選ぶ。

2. 室全長は適當の長さとして所要窒長は出來得る限り短かく選 ぶ。

3. 流速は出來得る限り早くする(但し 4 に觸れざる限度とす)。

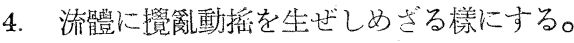

が擧げられる。佮實際問題として流體を自由に選ぶことが出來れば 收麇としては出來る限り密度の小なる流體を選べばよく, 選粉選粒 には粒子の密度以下に於て出來得る限り密度大なる流體を選べば效 果的である。

\section{VI 收旺室の高さが收暨量に及ぱす影響}

以上述ぺたことは重力に依る粒子の自然沈下を利用する收麙或は 選粉，選粒に關する理論的な一考察で實際上に於ては流水の攪亂， 動摇, 粒子の形狀又は內部狀態等の影響で理論式同樣の結果が得ら

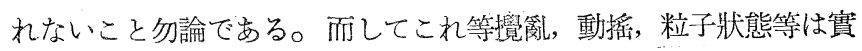
狀に低りその影響を異にするもので畫一的に影響を及ぼすものでな い故, 1裝置に依る 1,2 の實驗より一般的に裝置の明確な效果限度を 定めることは困難であるが, 概略の傾向だけは察知出來ると考へら れる。

著者は最近收鹿問題を件ふ１實踰を行ふ機會に惠采れ 2,3 の實 測を行つたので明確な限度 $(r, x$ の明確な關係)には觸れず相對的 な傾向に就て記述して見ようと思ふっここの實驗は裝置其他に不充分 な黣が多く目つ實驗上各種の制限が加へられた雲, 組織的な精細な 實驗は行ひ得なかつたが事情上止むを得なかつたことを附言する。

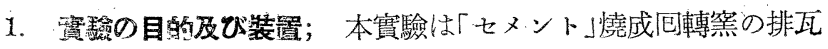
斯に含有される粉麇を收塵するのに收蝔室の長さ及其他の條件を一 定し收歔窒の高さだけを變化せしめてこの高さの變化に件ひ沈蝔量 が如何に變化するかを調べる目的で行つたものであるが實際實驗に 着手して見ると一定であることを望む各種條件が雔想外に變化甚だ しく僅かな實測值は俄に信が置けないことが觀取された。一方「セ メント」工場は周知の通り三ヶ月每に運轉が切替へられる䉆三ヶ月 間に全實驗をすませなければ比較困難となる鹪各種高さの違ふ多數 の收塺室を作つて同時に多數の實測を行ふか或は一つの裝置を改造 して高さを變化せしめる場合はその種類を減少しその各種類の實測 包數を多くするより外に手段がない。而して理想としては前者に依 つてなす實驗が望ましいのであるが實際問題（取付の方法）より考 へてこれは困難が多く結局本實驗は後者に依つて行つた。改造によ る收塵室の高さの變更も一々實高を變へることは日數が少なくその 棂がないので茲に於ては第 4 圖汇示す如く內矩 1.8 米 $\times 1.8$ 米 $\times 6$ 米の長方形の室を作りこの內部に同圖 $\mathrm{A}-\mathrm{A}$ 斷面圖, B-B 岰面圖に 示す樣な仕切を設けこの仕切板を拢差することに依り收鷹室の高さ を變化させたと同樣の效果をもたせる樣工夫した。仕切板は水平面 
第 4 圖

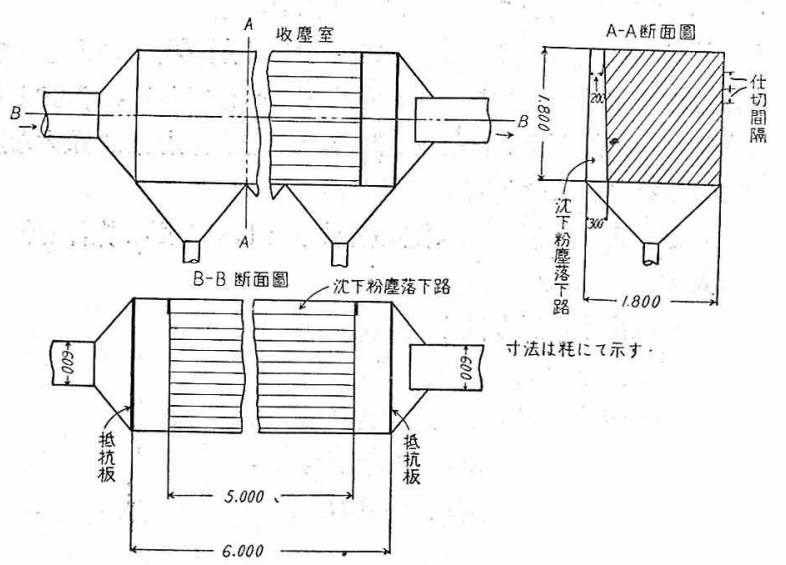

第 5 圆

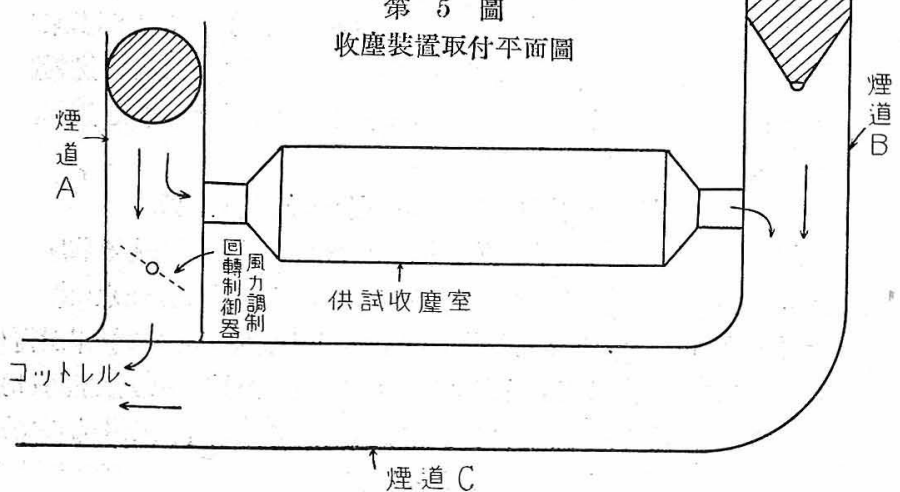

壻

臬
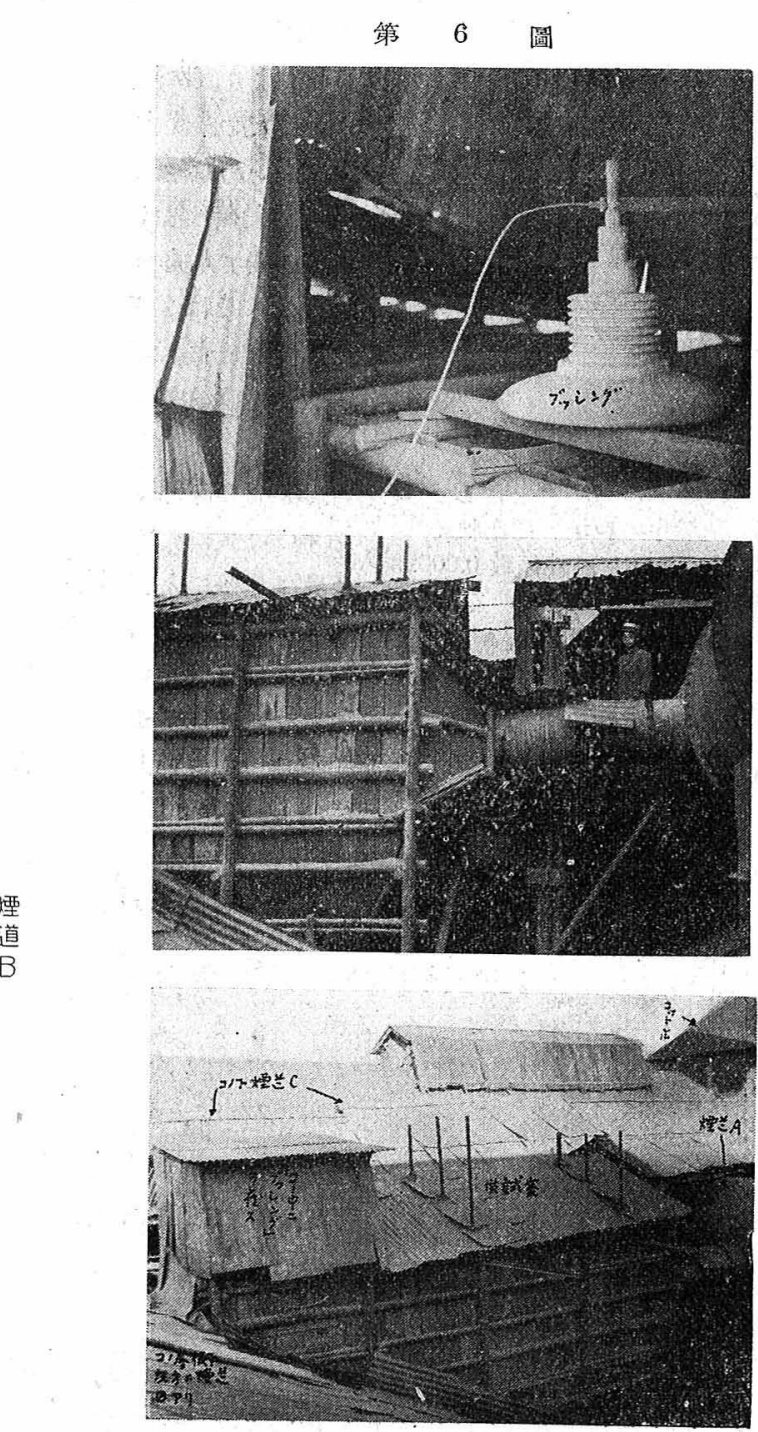

2. 菑驗; 實驗は內部の仕切間隔を 20 糎とした場合, 40 糎とし て場合及仕切を全然無くした場合の三通について行つたものである がこの實驗は他の實驗の從屬實驗であつた關係上第 1 室より第 4 室迄の全室を仕切つて行つた實驗は仕切間隔 20 糎のものだけでこ の裝置で 1 ケ月間實測を行ひ其後第 4 室を「コットレル」類似の裝 置に改造し第 1 公より第 3 室迄仕切を施しこの仕切間隔を 20 粝, 40 粧及仕切を全部なくして實測したものである。この後の場合に於 ても嘪驗は主として仕切間隔 20 糎のものに就て行ひ他は單に概略 を比較する程度に止めた。仕切間隔 40 糎及仕切無しの場合に就て も充分實驗したかつたが日數がなく且つ仕切間隔 40 糎實測值を見 るに䂆想と大部開きはあるが大體の輪廓は挸まれる樣考へられたの で俄に仕切を全部拢取り餘日を以つて仕切なしの場合の沈塺量實測 を行つた。この最後の實測值は豫想と甚だしい開きを示してるるが これは仕切間隔 20 粧及 40 糎の仕切が斜面で仕切つてあるのに對 し仕切無しのものは直接間隔になつてるる雼と考へられる。仕切間 隔 40 輝の實測值更に實測可數を多くすべきであつたことを痛感し てるる。收麈裝置は便宜上基底を 4 區畫に等分しその 1 區畫に一つ 宛粉麇溜を設けた。收塵室本體には流れに直乍な區畫は設けなかつ たが，一つの粉塺溜の上にある收歴空の部分を 1 區畫と見做し流體 の大口より順に第 1 室, 第 2 室…と呼ぶことにした。收麂室內 の風速は 1 米とする樣計畫したのであるが既記の樣な都合でこれが 望まれず且つ實測も出來なかつた第如何なる速度分布をるつてるた 
か不明である。參考として瓦斯導大管及排出管に於ける瓦斯の速度

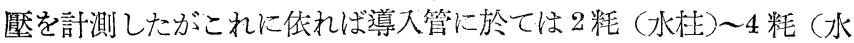

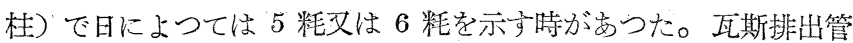

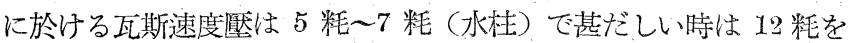
示したことがある。瓦斯溫度は大口に於て $160^{\circ} \sim 190^{\circ} \mathrm{C}$ で出口の瓦 斯溫度は $15^{\circ} \sim 30^{\circ} \mathrm{C}$ の低下を示す。沈塺量の賽測は入口風壓が甚 だしく違ふ時は記錄として探錄しなかつたがそれにも不拘ず實測値 は各四により甚だしい變化がある。これは流速, 溫度等の變化が影 響を及㴗すであらうことは刎論である。更に本質的な原因がなけれ はならないと考へられる。而してこの本質的な原因は當社に於ける 各種の記錄を參照するに流體そのものにあるらしく包轉等の排瓦斯 の含塵量は甚だ變化の多いものであると制紤される樣である。依而 斯如き秃統に於て收魁窒の良否を比較する場合は唯單に沈塺量の實 測值のみより比較することは危險が多く結局收塵率を測定するか止 むを得ない場合は沈應量實測回數を非常に多くしてその結果より制 斷すべきであると思はれる。本實驗に於ては收塺率の測定を行つて をらず各種類の泌杯量の實測も仕切間隔 20 糎のものを除いてはそ の實測可數が少なく從つて沈塺量の實側值そのものより直ちに正し い比較は出來ないが概略の傾向を示すものとして實測結果を採錄す る。第 1 表は第 1 室より第 4 室迄全室を 20 糎間隔に仕切り每四 2 時間瓦斯を通して沈下微蝔量を計測したもので第 2 表は第 4 室を改 造して「コットレル」類似の裝置を取付け第 1 室より第 3 室迄を 20 糎間隔に仕切つた場合 40 粝間隔に任切つた場合及全仕切を取除い た場合に付き每包 2 時間瓦斯を通して沈下微塵量を計測したもので ある。この表より明かである樣に第 1 表と第 2 表の第 3 項とは第 4 室の構造が變つてるるだけに過ざないが沈塺量は兩者に於て非常に 大きな開きを來してるる。而してこの開きは唯單に第 4 室の構造の 變化に依つて招來されたと考ぶ゙きかどうかは疑問でこれは更に檢 討を加へるつもりであるが，この結果の精細な檢热は後報に讓り本
第 7 圖 實測値の相互關係

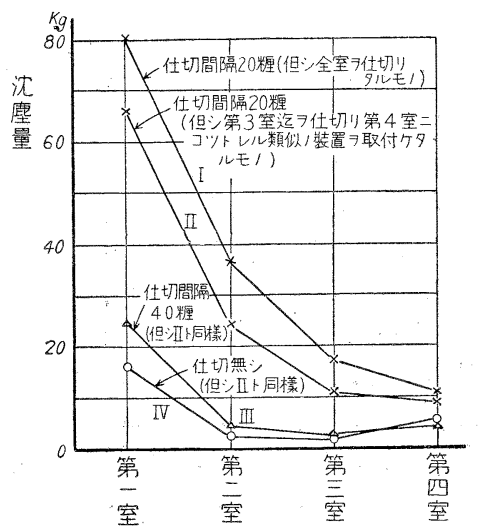

報告に於ては單に實驗結果 を羅列するに止める。佮意 味はないことか子知れない が相互關係が一覽出來る樣 實測傎を曲線で示せば第 7 圖となる。佮本實驗は室高 の變化に伴ふ沈應量の變化 を調べる目的で實驗したの であるが沈歴量を室別に計 測した篇間接に室長と收塵 量との關係が類推される。 室長と收塺量との關係は粉 應の粒度組成, 流體の速度 更收蔍室の高さに影響され
るところ甚大で輕々に論ずることは出來ないが概して云へば收塵に 有效な窒長には限度があり, それ以上室長を長くしても大なる效果 は擧げ得られないことが第 7 圖 I, II の曲線より推察される。これ 等の問題に關する詳細なる吟味檢討は第 131 報に讓り實測值の示す 概略の傾向のみより結論すれば次の樣になる。

$$
\text { 第 } \mathrm{r} \text { 表 }
$$

試驗裝置の仕切間隔を $20 \mathrm{~cm}$ としを時の沈塺量賽測值(單位醋)

$\begin{array}{rrrrrr}\text { 回 } & \text { 第1室 } & \text { 第2室 } & \text { 第3 室 } & \text { 第 } 4 \text { 室 } & \text { 合 計 } \\ 1 & 50.7 & 17.5 & 8.9 & 4.9 & 82.0 \\ 2 & 38.9 & 14.4 & 6.7 & 5.0 & 65.0 \\ 3 & 63.9 & 17.3 & 11.0 & 6.3 & 97.5 \\ 4 & 41.9 & 20.4 & 6.8 & 3.6 & 72.7 \\ 5 & 78.8 & 28.7 & 11.2 & 6.7 & 125.4 \\ 6 & 66.3 & 31.9 & 14.0 & 8.8 & 121.0 \\ 7 & 52.6 & 19.7 & 10.6 & 6.5 & 89.4 \\ 8 & 72.1 & 16.7 & 9.3 & 7.2 & 100.3 \\ 9 & 51.5 & 19.9 & 10.5 & 5.7 & 87.6 \\ 10 & 73.2 & 25.8 & 11.0 & 6.7 & 116.7 \\ 11 & 64.6 & 31.6 & 17.2 & 12.0 & 125.4 \\ 12 & 66.3 & 24.1 & 12.5 & 7.7 & 110.6 \\ 13 & 33.7 & 16.8 & 6.1 & 3.4 & 60.0 \\ 14 & 56.1 & 23.2 & 10.2 & 4.8 & 94.3 \\ 15 & 88.6 & 39.6 & 19.9 & 14.7 & 162.8 \\ 16 & 78.8 & 25.5 & 10.0 & 6.2 & 120.5 \\ 17 & 67.0 & 22.1 & 10.5 & 5.3 & 104.9 \\ 18 & 73.6 & 26.9 & 10.2 & 7.2 & 127.9 \\ 19 & 108.0 & 59.8 & 37.9 & 21.6 & 227.3 \\ 20 & 67.3 & 18.7 & 5.0 & 6.5 & 97.5 \\ 21 & 1098 & 46.8 & 20.0 & 16.4 & 193.0 \\ 22 & 127.6 & 56.1 & 30.5 & 16.9 & 225.1 \\ 23 & 76.5 & 27.8 & 7.8 & 7.2 & 1193 \\ 24 & 97.4 & 51.8 & 18.9 & 13.2 & 181.3 \\ 25 & 86.8 & 62.3 & 32.6 & 19.9 & 201.6 \\ 26 & 95.4 & 47.8 & 28.1 & 18.1 & 189.5 \\ 27 & 88.4 & 41.0 & 12.9 & 8.1 & 150.4 \\ 28 & 80.9 & 36.1 & 14.7 & 8.9 & 140.6 \\ 29 & 78.5 & 26.4 & 14.1 & 5.2 & 124.2 \\ 30 & 140.2 & 78.6 & 44.0 & 25.3 & 287.8 \\ 31 & 73.7 & 39.2 & 10.6 & 9.1 & 132.6 \\ 32 & 95.5 & 42.0 & 14.4 & 7.5 & 159.4 \\ 33 & 74.1 & 26.2 & 7.9 & 6.0 & 114.2 \\ 34 & 116.8 & 51.3 & 23.5 & 13.6 & 205.3 \\ 35 & 99.2 & 74.1 & 38.9 & 28.0 & 234.2 \\ 36 & 117.2 & 77.1 & 31.5 & 21.6 & 247.4 \\ 37 & 66.3 & 21.8 & 11.6 & 8.1 & 107.8 \\ 38 & 105.6 & 47.2 & 31.7 & 19.5 & 204.0 \\ 39 & 69.8 & 28.6 & 15.8 & 10.6 & 124.8 \\ 40 & 65.5 & 49.0 & 23.9 & 16.9 & 155.3 \\ 41 & 135.8 & 68.5 & 23.3 & 17.2 & 244.8 \\ & 80.2 & 36.8 & 17.0 & 10.8 & 144.8\end{array}$

第 2 表 試驗裝置に於ける沈塺量實測値 (每 2 時間の沈塺量)

但し第 4 窒は任切を䛇さず「コットレル」類似の裝置を取付けをるものなり（單位䣶）

\begin{tabular}{|c|c|c|c|c|c|}
\hline & & 切を入 & しない时 & 沈塺量 & \\
\hline 回 & 第 1 室 & 第 2 室 & 第 3 室 & 第 4 窒 & 合計 \\
\hline 1 & 9.6 & 0.9 & 0.7 & 4.5 & 15.7 \\
\hline 2 & 9.8 & 0.8 & 0.6 & 4.2 & 15.4 \\
\hline 3 & 5.0 & 0.4 & 0.6 & 3.3 & 9.3 \\
\hline 4 & 16.4 & 1.5 & 0.8 & 5.3 & 24.0 \\
\hline 5 & 16.3 & 1.8 & 1.3 & 7.3 & 26.7 \\
\hline 0 & 8.7 & 2.3 & 0,9 & 1.6 & 13,5 \\
\hline
\end{tabular}




\begin{tabular}{|c|c|c|c|c|c|c|c|c|c|c|c|c|c|c|c|c|}
\hline 11.2 & 1.1 & 0.6 & 2.7 & 15.6 & 7 & 21.8 & 4.9 & 2.6 & 5.0 & 34.3 & 7 & 57.7 & 39.3 & 18.9 & 16.4 & 132.3 \\
\hline 10.8 & 1.5 & 0.8 & 3.5 & 16.6 & 8 & 26.6 & 4.6 & 3.4 & 5.2 & 39.8 & 8 & 33.1 & 16.8 & 12.3 & 5.6 & 67.8 \\
\hline 13.2 & 1.6 & 1.2 & 4.2 & 20.2 & 9 & 24.8 & 5.3 & 2.9 & 4.5 & 37.4 & 9 & 55.5 & 15.9 & 5.3 & 5.3 & 82.0 \\
\hline 14.1 & 4.3 & 2.9 & 2.6 & 23.9 & 10 & 25.0 & 3.8 & 1.8 & 4.3 & 34.9 & 10 & 67.7 & 26.8 & 11.5 & 6.9 & 112.9 \\
\hline 25.8 & 3.8 & 1.3 & 8.4 & 39.3 & 11 & 19.4 & 2.7 & 1.7 & 4.2 & 28.0 & 11 & 76.3 & 24.2 & 11.2 & 8.8 & 120.5 \\
\hline 14.0 & 2.6 & 1.8 & 7.1 & 25.5 & 12 & 17.9 & 3.4 & 1.9 & 4.4 & 27.6 & 12 & 55.3 & 21.5 & 9.0 & 11.2 & 67.0 \\
\hline 14.9 & 4.2 & 2.1 & 6.4 & 27.6 & 13 & 27.1 & 4.6 & 2.3 & 4.9 & 38.9 & 13 & 93.4 & 35.8 & 14.5 & 14.8 & 158.5 \\
\hline 9.2 & 2.1 & 2.5 & 3.8 & 17.6 & 14 & 30.9 & 5.1 & 3.1 & 5.1 & 44.2 & 14 & 92.5 & 30.5 & 14.4 & 10.2 & 147.6 \\
\hline 15.4 & 2.0 & 1.0 & 4.8 & 23.2 & 15 & 45.2 & 9.0 & 5.3 & 8.3 & 67.8 & 15 & 72.1 & 25.6 & 11.6 & 9.8 & 119.1 \\
\hline 10.0 & 1.2 & 0.4 & 1.6 & 13.2 & 16 & 35.4 & 7.8 & 4.1 & 6.5 & 53.8 & 16 & 85.1 & 25.1 & 10.5 & 10.4 & 131.1 \\
\hline 15.7 & 1.2 & 0.7 & 3.8 & 21.4 & 17 & 34.3 & 7.1 & 4.5 & 6.0 & 51.9 & 17 & 75.5 & 24.5 & 11.5 & 9.8 & 121.3 \\
\hline 26.7 & 2.6 & 1.9 & 5.0 & 36.2 & & & & & & & 18 & 77.3 & 24.8 & 8.9 & 12.3 & 123.3 \\
\hline 16.5 & 3.8 & 3.1 & 6.2 & 29.6 & & & & & & & 19 & 77.4 & 32.0 & 13.0 & 11.5 & 133.9 \\
\hline 19.7 & 3.5 & 1.8 & 6.1 & 31.1 & & & & & & & 20 & 84.9 & 33.5 & 12.9 & 15.1 & 146.4 \\
\hline 21.4 & 3.6 & 7.8 & 7.4 & 40.2 & & & & & & & 21 & 73.1 & 27.8 & 14.7 & 9.4 & 125.0 \\
\hline 18.7 & 2.8 & 1.6 & 4.7 & 27.8 & & & & & & & 22 & 74.5 & 22.8 & 10.8 & 9.3 & 117.4 \\
\hline 38.8 & 11.7 & 6.8 & 12.8 & 70.1 & & & & & & & 23 & 91.0 & 31.6 & 17.0 & 16.3 & 155.9 \\
\hline 23.0 & 7.3 & 7.6 & 14.6 & 52.5 & & & & & & & 24 & 94.5 & 42.3 & 24.9 & 12.2 & 173.9 \\
\hline 24.2 & 4.4 & 3.2 & 9.1 & 40.9 & & & & & & & 25 & 39.7 & 12.1 & 2.9 & 3.9 & 58.6 \\
\hline & & & & & & & & & & & 26 & 39.6 & 20.4 & 8.1 & 6.7 & 74.8 \\
\hline & & & & & & & & & & & 27 & 65.9 & 18.5 & 7.8 & 7.3 & 90.5 \\
\hline & & & & & & & & & & & 28 & 78.0 & 25.9 & 10.6 & 7.8 & 122.8 \\
\hline & & & & & & & & & & & 29 & 39.8 & 17.0 & 7.8 & 10.1 & 74.7 \\
\hline & & & & & & & & & & & 30 & 61.0 & 17.4 & 6.6 & 5.2 & 90.2 \\
\hline & & & & & & & & & & & 31 & 45.2 & 13.6 & 6.2 & 5.2 & 70.8 \\
\hline & & & & & & & & & & & 32 & 65.4 & 19.6 & 7.4 & 6.2 & 98.6 \\
\hline & & & & & & & & & & & 33 & 62.0 & 17.2 & 6.4 & 6.9 & 92.5 \\
\hline 16.4 & 2.9 & 2.2 & 5.6 & 27.1 & 本均 & 24.8 & 4.4 & 2.5 & 4.4 & $\cdot 36.1$ & 平均 & 66.4 & 24.2 & 11.1 & 9.2 & 110.7 \\
\hline
\end{tabular}

3. 結論；（1）理諭式の解說に於て述べた收麼公高が沈㑌量に大 なる影響を及ぼすと云る、點は大體に於て實證された樣に考へられ る。(2) 收塵室長が收栕量に大なる鬬係を有し收塺室長が大なれば 大なる程收塵量は習大するが收麈に有效なる室長には限度がある。
附、瞢 實驗には從業員を當てたが主として横田源次君が擔當し た。瓦斯塞止扉を漏れて裝置に流れ込む熱氣の中に粉塵にまみれて 實驗に倾注した同君及びその手足となつて働、た從業員諸君の勞を 大いに多とするものである。

\section{Abstract \\ ON TEE DUST COLLECTING OR SEPARATING I'ROBLEM, II.}

By J. Isobe

In the preceding report, author discussed a motion of particle moving in a horizontal steady flow and gave an equation of a moving particle. In the present article, locus of motion of particle repressented by the equation are graphically explained and pointed out the necessary conditions for dust collecting or separating apparatus utilizing such a moyion.

Efficiency of dust chamber or separator mainly depends on the chamber height, chamber length and velocity of fiuid. A dust chamber must be biult as low and long as possible, while a separator, on the contrary, must be biult properly heigh and short. This fact is also roughly reproved in my experience of dust setting of rotary kiln gas. On the dust chamber (its dimensions are $1,8 \mathrm{M}$ height, $1,8 \mathrm{M}$ width and $6 \mathrm{M}$ long) kiln gas deposits about $27 \mathrm{~kg}$ of dust but if the chamber is devided by every $40 \mathrm{~cm}$ height, then the deposit dust becomes about $36 \mathrm{~kg}$ and if devided by every $20 \mathrm{~cm}$ height, deposit becomes about $110 \mathrm{~kg}$. 